\title{
PRESS COVERAGE OF ETHNIC INTEREST GROUPS IN NIGERIA: A STUDY OF SELECTED NATIONAL DAILIES
}

\author{
Henry Chigozie Duru, PhD \\ Department of Mass Communication, \\ NnamdiAzikiwe University, Awka, Nigeria
}

\begin{abstract}
Ethnic interest groups constitute influential actors in Nigeria's sphere of political engagement and public discourse generally. These groups, like other social actors, largely rely on mass media to be seen and heard, and the way media report them tends to shape public perception and engagement with the groups. Therefore, this paper examined press coverage of ethnic interest groups in Nigeria. Situated within the framework of agenda setting and framing theories, the study was designed as a content analysis. Four national dailies -Daily Sun, Vanguard, The Nation and Daily Trust - were purposively selected between May 29, 2015 and May 29, 2017, while 432 editions (108 issues for each paper) were selected. Findings showed that newspapers gave frequent and prominent coverage to ethnic interest groups in Nigeria. Reports on the groups revolved mainly around advocacy and antagonistic communication from the groups. The reports were slanted to favour ethnic groups of the respective owners. The study concluded that the continued visibility enjoyed by ethnicity-related issues in the sphere of public discourse in Nigeria may be partly explained by the frequent and prominent coverage given to them by newspapers, and that newspapers' slanting of their reports in favour of ethnicity of their owners underscores their role in reinforcing ethnic consciousness and divisiveness in Nigeria as found by several previous studies. The study recommended, among others, more efforts by the press towards objectivity and non-sensationalism in their reportage of ethnicity.
\end{abstract}

Keywords: Press, Coverage, Ethnicity, Ethnic interest groups, Newspaper

\section{INTRODUCTION}

Ethnic politics has become a defining phenomenon in Nigeria's nationhood (Adetoye, 2016). An important actor in this ethnic politics has been ethnic interest groups which are non-state bodies that project interest of respective ethnic groups they represent. Historically, the activities of these groups had begun long before the independence of Nigeria in 1960. In fact, their rise and growth in prominence can be attributed to the rise of ethnic consciousness in the country, as the amalgamation of 1914 foisted the co-existence under one political roof of peoples of widely differing ethnic and cultural backgrounds (Eric, 2016).

As it turned out, that British-imposed unification has left in its trail a long-running tale of tensions, frictions and bloody clashes that have become a recurring decimal in the Nigeria's political journey (Edewor, Aluko \& Folarin, 2014), with the civil war of 1967 - 1970 arguably being the climax so far. Consequently, from the outset, Nigeria became burdened by ethnic divisiveness which immediately inscribed its mark on every aspect of the life of the emerging nation. Hence, the early socio-political institutions, including political parties and the press, became infected with the pervading ferment of ethnicity (Daramola, 2013; Nwafor, 2015). The nation became inscribed with what Umejesi (2012) describes as "grievance dynamics" manifesting as "contestation for sovereignty" between the state and previously independent local (ethnic) communities (p.47).

Beginning from 1953, there have been tens of ethnic crises in Nigeria resulting in uncountable deaths and property destruction (Sagay, 2009; Ndujihe, 2011). Incidentall 
given the interlocking of religion and ethnicity in the country, especially in the context of the north-south divide, many of these crises have also come with some religious undertone.

Thus, ethnicity has emerged a very powerful force shaping the socio-political landscape of Nigeria. It is an important factor in the structuring of the country starting from its initial regional set-up to the current state arrangement (Vande, 2012; Kasali, 2013; Adetoye, 2016). Similarly, several policies of the country including notably the federal character principle and revenue sharing system have been influenced wholly or partly by ethnicity (Ojie \& Ewhrudjakpor, 2009). In fact, the footprint of ethnicity remains visible in virtually all facets of national life.

Ethnic interest groups arguably constitute the major voice of ethnicity in Nigeria. These interest groups essentially have their ultimate objective as to project and fight for the interest of the respective ethnic segment they seek to represent. These groups, whose presence has been felt since the pre-independence era (Nnoli, 1978), now serve as the key corporate voice of ethnicity and ethnic groups in the country. Some of them such as ACF, Ohanaeze, Afenifere and Ibibio People's Union are more conservative and conformist, while others such as MASSOB, MOSOP, IPOB and OPC are more radical and tend towards self-determination. These bodies are informal entities in that they have no formal place in the politico-legal setup of the country. Unlike other political groupings (such as state and local governments), their existence and activities are permitted and not commanded by law. However, they have become quite influential in political discourse and engagement in the country (Kukah, 2012). Notably,ethnic interest groups are an important actor in the unity-versus-division politics in Nigeria, as their claims and actions often have implications for national cohesion and peace (Ayatse\&Akuva, 2013).

Consequently, understanding the ethnic interest groups is important for appreciating the dynamics of ethnicity and ethnic politics in Nigeria (Nnoli, 1978). In the same vein, understanding how the media represent these groups will be important for appreciating how ethnicity is generally represented in the media. These ethnic interest groups operate and communicate within a very vast geographic and cultural space known as Nigeria; and so, like other political actors and interests, they require mass media to be able to assert a presence within this huge space. It is what media report about the groups that members of the public tend to known about them. Therefore, media reportage becomes critical to how society relates with these groups and how their activities impact society. More importantly, such coverage contributes critically in shaping ethnic discourse and ethnic relations in the country. Against this backdrop, this paper studied press coverage of ethnic interest groups in Nigeria with focus on selected national daily newspapers.

\section{STATEMENT OF THE PROBLEM}

In Nigeria, ethnicity has been identified as a major problem. It has been blamed for all sorts of counter-developmental tendencies in the country including strife, violence, nepotism and corruption (Ayatse\&Akuva, 2013). In fact, Ayatse and Akuva (2013) claim that ethnicity "has been discovered to have been responsible for most of the political, administrative, economic, social and cultural maladies in Nigeria" (p.178). Hence, ethnic interest groups, who champion ethnic claims, maintain an uneasy presence in the polity - as their activities often bear the potential for inciting tensions and conflicts (Ayatse\&Akuva, 2013). With the media thrown into the middle of these tensions and disputes, they arguably walk a tight ethical rope as their professionalism is brought under pressure. 
Studies on press reportage of ethnicity (such as Omenugha \& Ukwueze, 2011; Ngwu, Ekwe \& Chukwuma, 2013; Nwafor, 2015) point to biases on the basis of the ethnicity of owners. This would suggest that newspapers, as against objectively engaging ethnicity, are also implicated in ethnic politics.

\section{OBJECTIVES OF THE STUDY}

The aim of this study was to investigate press coverage of ethnic interest groups in Nigeria with focus on selected national daily newspapers. More precisely, the following objectives are targeted:

i. To find out how frequently newspapers reported ethnic interest groups in Nigeria;

ii. To find out how much prominence newspapers accorded these interest groups;

iii. To identify issues and events the newspapers reported of the groups;

iv. To ascertain the slants of newspaper reports on the ethnic interest groups; and

v. To establish the likely influence of owner's ethnicity on newspaper coverage of the groups.

\section{RESEARCH QUESTIONS}

In view of the above objectives, the following research questions are formulated to guide the study:

1. How frequently did newspapers report ethnic interest groups in Nigeria?

2. How much prominence did newspapers accord these interest groups?

3. What issues and events did newspapers report of the groups?

4. What were the slants of newspaper reports on the ethnic interest groups?

5. What was the likely influence of owner's ethnicity on newspaper coverage of the groups?

\section{SIGNIFICANCE OF THE STUDY}

Studies on media and ethnicity in the country have predominantly focused on specific ethnicity-related issues and events (Medubi, 2002; Anim, 2007; Salawu, 2013; Ngwu, Ekwe \& Chukwuma, 2013; Sule, 2015). This study however focused on the overall activities of all ethnic interest groups in the country in order to have a more holistic picture. This approach was significant given that these groups have been described as the major organised voices of ethnicity in the country (Nnoli, 1978); hence their activities and communications offer a vital understanding of ethnic relations and discourses in Nigeria. By focusing on their reportage, therefore, this study arguably added some depth to the extant empirical literature in the area of ethnicity and media.

Newspapers (and perhaps other forms of mass media such as TV and radio) in Nigeria could benefit from this study by way of gaining some form of feedback on their performance in reporting ethnic interest groups and ethnicity in general. In other words, these newspaper houses could find the data to be generated by the research useful for self-assessment and possible improvement in their reportage of ethnicity.

Similarly, the government and other stakeholders in Nigeria's sphere of political relations could find the data to be generated by this research useful for enhancing ethnic cohesion and national unity. Since the mass media play a dominant role in how ethnic consciousness and ethnic relations are generated and shaped (Brooks \& Hébert, 2006), understanding how newspapers in Nigeria represent ethnicity could offer some useful insight to government and other stakeholders towards better management of ethnic relations in the country. This 
improved management is required at this time the nation is experiencing an upsurge in the activities of secessionist groups such as MASSOB and IPOB.

\section{SCOPE OF THE STUDY}

The study focused on press reportage of ethnic interest groups in Nigeria. While this subject encompasses a lot of issues, this study concerned itself with only five variables as reflected in the objectives of the study i.e. frequency, prominence, issues, slant and possible influence of owners' ethnicity on coverage.

Also, the study restricted itself to only national dailies being that they constitute the mainstream in the nation's newspaper industry (Eze, 2017). Further, data collection was confined to only four newspapers; however, they were selected in such a way that they would represent the ethnic spread of ownership and readership of newspapers in Nigeria. Similarly, the study was delimited to a two-year period.

\section{LITERATURE REVIEW}

\section{ConceptualisingEthnicity}

Like other forms of social identity, ethnicity is not easily definable. But basically, ethnic identity is ascribed to persons based on their membership of a certain form of collective known as ethnic group. Defining ethnic groups, Ukiwo (2005) opines that they are groups with ascribed membership, usually but not always founded "on claims or myths of common history, ancestry, language, race, religion, culture and territory." Although these factors need not necessarily be present before a group is identified as an ethnic group, the basic thing is that such a group is attributed with a common identity that differentiates it from others. Therefore, ethnicity is a very complex and fluid form of identity generated via interpenetration of all or some of the following variables: history, race, language, culture, religion and geography (Nnoli, 1978). In Africa, nonetheless, language has been identified as the most common variable in ascribing ethnicity (Ademola, 2009).

However, ethnicity does not isolate itself; it reaches out and interlocks with other identity forms including political, economic, social, religious, class and other shades of identity. This makes ethnic identity fluid as people can cross ethnic boundaries. Frank Salamone (as cited in Kukah, 1993) avers that ethnic "boundaries are permeable, and people, sometimes singly and sometimes in groups, cross them. They do so in general, either to maximise their opportunities or to minimise or neutralise their threats" (p.1 -2). This fluidity of ethnicity has been particularly advanced by the critical school including in particular postmodernism and Marxism (Nnoli, 1978; Waters, 2009; Omoniyi, 2014).

After New Guinea and Indonesia, Nigeria ranks as the most ethnically and linguistically diverse country in the world (Blench \& Dendo, 2003). Apparently, no agreement has been reached as to the exact number of ethnic groups in Nigeria. However, popular views have put this at between 250 and over 300 (Blench \& Dendo, 2003; Ayatse \& Akuva, 2013; Nwafor, 2015). The nation is a multi-ethnic entity where three major ethnic groups - Hausa-Fulani, Igbo and Yoruba, and tens of smaller groups have had to coexist under one political roof.

Undoubtedly, ethnicity has been a recurring component of power relations in Nigeria (Ekeanyanwu, 2007; Ademola, 2009; Ojie \& Ewhrudjakpor, 2009; Ayatse \& Akuva, 2013; Ekeanyanwu, 2013). In fact, it has been widely noted as one of the most powerful forces that have shaped the country's history, for good or for bad (Blench \& Dendo, 2003; Ukiwo, 2005 
Ajayi \& Owumi, 2013). Ebegbulem (2011) argues that the influence of ethnicity has been pervasive, having a major impact on Nigeria's political and economic growth, influencing selection of leaders, siting of industries and other developmental projects; it brews interethnic hostility and violence and generally undermines national unity and socio-economic wellbeing. Ethnicity exerts visible influence on the process of policy formulation and institution development in Nigeria (Ojie \& Ewhrudjakpor, 2009).

\section{Ethnic Interest Groups}

An important actor in ethnic relations in Nigeria is the ethnic interest groups. These groups have as their main objective the pursuit of the interest of their respective ethnic groups. The rise of ethnic interest groups in Nigeria dates back to the colonial era with the Ibibio State Union, founded in 1927, reportedly being the first to come into existence. Today, the organization bears the name, Ibibio People's Union. The Igbo State Union was another ethnic interest group that came up in those early days (Orizu, 1994). The EgbéỌmọOdùduwà, which was a Yoruba interest group, was founded in 1945 while a Hausa group, Jam'iyyar MutanenArewa, came subsequently (Nnoli, 1978).

However, the ethnic interest groups that still exist today came much later than these pioneer bodies. The OhanaezeNdigbo was founded in 1976 to represent Igbo interest (OhanaezeNdi Igbo, Enugu State Chapter, 2015). The Arewa Consultative Forum (ACF) came in 2001 (ArewaConsultative Forum, 2016) to represent the interest of northern ethnic groups, while both O'odua People's Congress, OPC (founded in 1994) and Afenifere are Yoruba interest groups (O'odua People's Congress, 2015). Within the context of the Niger Delta struggles, the Movement for the Survival of Ogoni People (MOSOP) founded in 1990 and the Ijaw Youth Council founded in 1998 were some of the high profile interest groups (Ojoma, 2015).

Worthy of note also is that ethnic interest groups sometimes are organized around other interests such as profession, education or gender. Groups organized around education include students' groups like National Union of Ikwere Students, National Union of Urhobo Students, National Association of Igbo Students, Yoruba Students Association, Hausa Student Association of Nigeria, National Association of Ijaw Female Students, National Union of Isoko Students, and Igala Students' Association, among others. Those organized along gender include women's groups like Ikwere Women Progressive Union, Ijaw Women's Association, and Association of Bini Women of Honour, among others (Ojoma, 2015).

While ethnic interest groups generally promote interests of their respective ethnic groups, ideology and method sometimes differ from one group to another. Some of the groups could be considered more conservative while others could be considered more radical by virtue of their more drastic demand such as self-determination. Among the former groups would include ACF, Afenifere and Ohanaeze while MASSOB, OPC and MOSOP could easily fall into the latter category.

\section{Media and Ethnicity in Nigeria}

Literature has implicated the media in the rise of ethnic consciousness in Nigeria (Kukah, 1993; Taiwo, 2007; Daramola, 2013; Nwafor, 2015). In his fairly detailed historical analysis, Daramola (2013) shows that Nigerian newspapers have from the outset been tied to the apron string of their owners, hence becoming partisan and tribal as necessitated by the respective political and ethnic affiliations of these owners. Some of the earliest newspapers established in the country as well as the broadcast stations that came later assumed ethnic colouration as politicians who established them employed them in pursuit of regional interests (Nwafor, 
2015). Two of these early newspapers, West African Pilot and Daily Service, owned by Dr. NnamdiAzikiwe and Ernest Sessei Ikoli respectively, had reportedly been in a feud which at times assumed ethnic colouration.

This feud, according to Omu (as cited in Daramola, 2013), contributed to "the regionalisation of nationalism and crystalisation of inter-group tension and animosity which characterized political developments for a long time" (p.41). Daramola (2013) contends that the ethnic cleavages evident in newspaper content in Nigeria are so obvious that one cannot but easily decipher them. Taiwo (2007) specifically accuses the Nigerian media of sensationalism in reporting ethnicity which sees them unduly focusing on conflicts in their coverage of ethnicity-related issues. This charge incidentally has been confirmed by empirical studies (Njoroge, Kimani \& Kikech, 2011; Doki, n.d.).

Studies on newspaper reportage on key national issues in the country have also shown that many of the reports tend to take sides on ethnic, political, regional or religious issues. Salawu (2007), Omenugha and Ukwueze (2011), Ngwu et al. (2013), Nwafor (2015) and Sule (2015) found that media coverage of ethnic issues was less than objectives as each establishment tended to slant its report in favour of a given ethnic group. Ownership has also been found as factor, as reports seemed to have been slanted to favour the owner's ethnic group (Salawu, 2007; Ngwu et al., 2013; Sule, 2015).

While the studies cited above are on media reportage of ethnicity-related issues, none of them focused specifically on coverage of ethnic interest groups, which being the only organised corporate ethnic players in the Nigeria's socio-political sphere (Ojoma, 2015), arguably present an ideal case for assessing media representation of ethnicity in the country. Stated differently, these studies were restricted to specific ethnic issues with none focusing holistically on the activities of ethnic interest groups. This constituted the research gap necessitating this study.

\section{THEORETICAL FRAMEWORK}

The agenda setting theory helps to view Nigerian newspapers as being able to project issues in society, including as related to ethnic interest groups. The theory posits that media, through regular and prominent coverage, elevate issues to the level of public agenda. In other words, media determine how much visible an issue becomes in the domain of public discourse; it sets public agenda (McQuail, 2010; Baran, 2010). Hence, while media may not tell us what to think, they certainly tell us what to think about. Stated differently, the theory is not about media persuading us, but about media suggesting to us what to think about and talk about. This is what is known as priming; the process whereby media makes a news event or issue more visible than others. Thus, Nigerian newspapers, through their manner of coverage, may elevate issues related to ethnic interest groups to the status of public agenda.

Also relevant to newspaper coverage of ethnic interest groups is the framing theory which explains the process whereby an originator of communication builds into their message the perspectives which they want audience to read the message from. The basis of the theory is that any given issue, event or development can be viewed and understood from varying perspectives. Stated differently, every phenomenon can be seen through different frames of meaning depending on who is seeing and the circumstances of the seeing (Chong \& Druckman, 2007a; Chong \& Druckman, 2007b). Hence, framing has been described as "the process by which people develop a particular conceptualization of an issue or reorient their thinking about an issue" (Chong \& Druckman, 2007a, p.104). It is "a way of giving s 
overall interpretation to isolated items of fact" (p.380). A frame is developed "through selection, emphasis, and exclusion." A given frame makes people to direct their attention on certain messages while failing to see the other" (Ardèvol-Abreu, 2015, p.428). In other words, a frame determines what is perceived and what is not perceived, what is understood and what is not understood, what is felt and what is not felt (Ardèvol-Abreu, 2015).

Media gatekeepers in selecting and packaging news inevitably engage in framing. As all other members of society, they are not immune to social judgments and biases. Thus, McQuail (2010) contends that it "is almost unavoidable for journalists to" engage in framing "and in so doing to depart from pure 'objectivity' and to introduce some (unintended) bias" (p.380). Consequently, framing has been described as "an essential feature of news" (Tuchman as cited in Scheufele, 1999, p.106).

Within the context of this study, the framing theory helps to put in perspective the role of the gatekeepers in influencing the judgments and feelings of the audience by virtue of what they highlight and what they fail to highlight in their reportage of ethnic interest groups. Thus, the process of news production in regard to these groups could be understood from the perspective of the thought, judgment and emotion the gatekeepers intended to provoke in readers.

\section{METHODOLOGY}

This study was designed as a content analysis. The study population was all national dailies published in Nigeria from May 292015 to May 292017 which was the first two years of the President MuhammaduBuhari administration. This period was chosen given its significance within the context of recent ethnic contestations in Nigeria. The period followed a presidential and other elections mired in ethnic tensions in March and April 2015 (Batta, Batta \& Mboho, 2015), and these ethnic tensions lingered under the administration as the government continued to be accused of ethnic bias by some interests in the country (Ojoma, 2015). Ethnically charged issues such as attacks by Fulani herdsmen, agitations by secessionist groups like IPOB, MASSOB and Niger Delta groups, and arrest and detention of the IPOB leader Nnamdi Kanu and leader of the Shiite Islamic Movement Ibrahim ElZakzaky, among others, were all news stories with ethnic overtone in this period (Ojoma, 2015; Ezeonwuka \& Igwe, 2016). Within this period, a total of 22 national dailies were found to be publishing in Nigeria, and each would have presumably published 732 issues in the two-year period of the study which gives a total of 16,104 issues.

The sample size for the study was 432 newspaper editions. This size was chosen based on Basden and Wright's (1997) recommendation that selecting one edition per week would be appropriate for a newspaper study extending up to a period of six months - and this study extended to a two-year period. Hence, for each of the four newspapers used here, 108 editions were selected (one from each of the 108 weeks that ran between May 292015 and May 29 2017). These, on the whole, amounted to 432 editions.

This sample selection was conducted in two stages. The first stage involved selecting newspaper titles, wherein the researcher looked out for two major characteristics; first, the market strength of a title, and second, the ethnic background of the owner. Hence, the researcher purposively selected Daily Trust, The Sun, The Nation, and Vanguard. The second stage of the sampling involved choosing particular editions of the four newspaper titles. Here, the researcher's aim was to ensure that every day of the week (excluding Saturday and Sunday) was duly represented. 
The weekend editions were excluded being that their content and style are more in the nature of magazine than newspaper. In other words, they don't usually represent the typical newspaper tradition in terms of content and style (Bellhouse, 2005). In ensuring that all days of the week were evenly represented, the researcher was guided by the recommendation by Basden and Wright (1997) that selection of editions should occur in a regular interval that would ensure that successive days are chosen every other week. Thus, the researcher began by picking the first day that occurred within the first week of the study - Friday, May 29, 2015. Then, moving to the second week, he chose Monday edition (June 1), the third week, the Tuesday edition (June 9), the fourth week, Wednesday June 17 and so on. This process continued up to the last week of May 2017 where the Tuesday edition (May 23) was selected. On the whole, 108 editions for each of the four newspapers and 432 editions for the entire four become the sample

The units of analysis were news, features, editorials, pictorials and cartoons. A coding sheet was used as the data collection instrument. The researcher was assisted by coders, who were first trained and an inter-coder reliability test conducted using Kappa formula as put forward by Cohen (as cited in Lombard, 2010). The test result stood at 0.96 which amounted to $96 \%$ reliability. Data was quantitatively analysed using simple percentages.

\section{DATA PRESENTATION AND ANALYSIS}

\section{RQ1: How frequently did newspapers report ethnic interest groups in Nigeria?}

Frequency was measured by examining the number of times reports on ethnic interest groups were published in the newspapers. Data generated in that regard are as presented in Table 1.

Table 1: Frequency of Coverage

\begin{tabular}{lccccc}
\hline & $\begin{array}{c}\text { Daily } \\
\text { Sun }\end{array}$ & $\begin{array}{c}\text { The } \\
\text { Nation }\end{array}$ & $\begin{array}{c}\text { Daily } \\
\text { Trust }\end{array}$ & Vanguard & Total \\
\hline Editions with reports on & $75 \%$ & $52.8 \%$ & $47.2 \%$ & $89.8 \%$ & $66.2 \%$ \\
ethnic interest groups & $\mathrm{N}=81$ & $\mathrm{~N}=57$ & $\mathrm{~N}=51$ & $\mathrm{~N}=97$ & $\mathrm{~N}=286$ \\
Editions without reports on & $25 \%$ & $47.2 \%$ & $52.8 \%$ & $10.2 \%$ & $33.8 \%$ \\
ethnic interest groups & $\mathrm{N}=27$ & $\mathrm{~N}=51$ & $\mathrm{~N}=57$ & $\mathrm{~N}=11$ & $\mathrm{~N}=146$ \\
\hline Total & $100 \%$ & $100 \%$ & $100 \%$ & $100 \%$ & $100 \%$ \\
& $\mathrm{~N}=108$ & $\mathrm{~N}=108$ & $\mathrm{~N}=108$ & $\mathrm{~N}=108$ & $\mathrm{~N}=432$ \\
\hline
\end{tabular}

Table 1 shows that on the whole, $66.2 \%$ of the newspaper editions had reports on ethnic interest groups while $33.8 \%$ came with no such reports. Apart from Daily Trust, all of the newspapers had such reports in majority of their issues published within the period under study. Nevertheless, the number of Daily Trust editions with such reports was only slightly below majority. The foregoing indicates that ethnic interest groups were a regular news subject in the newspapers, at least within this period, suggesting that these groups and their activities are viewed as important and critical to the nation by the newspaper gatekeepers. This tends to reinforce the belief expressed by writers like Daramola (2013) and Nwafor (2015) that ethnicity has over the years constituted an important and recurring news subject in the Nigerian media.

RQ2: How much prominence did newspapers accord these interest groups? 
Volume 1 Number 2

Prominence was measured by examining the placement, page rating and headline size of reports published on ethnic interest groups in the newspapers. Data generated in that regard are as presented in Tables 2, 3 and 4.

Table 2: Placement

\begin{tabular}{lccccc}
\hline & & \multicolumn{2}{c}{ Newspapers } & \multicolumn{2}{c}{ Total } \\
& Daily Sun & The Nation & Daily Trust & Vanguard & \\
\hline Front page & $21.4 \%$ & $24.8 \%$ & $8.6 \%$ & $14.3 \%$ & $18 \%$ \\
& $\mathrm{~N}=60$ & $\mathrm{~N}=37$ & $\mathrm{~N}=12$ & $\mathrm{~N}=26$ & $\mathrm{~N}=135$ \\
Centre page & $0 \%$ & $0 \%$ & $2.1 \%$ & $0 \%$ & $0.4 \%$ \\
& $\mathrm{~N}=0$ & $\mathrm{~N}=0$ & $\mathrm{~N}=3$ & $\mathrm{~N}=0$ & $\mathrm{~N}=3$ \\
Back page & $0 \%$ & $0 \%$ & $0 \%$ & $0 \%$ & $0 \%$ \\
& $\mathrm{~N}=0$ & $\mathrm{~N}=0$ & $\mathrm{~N}=0$ & $\mathrm{~N}=0$ & $\mathrm{~N}=0$ \\
Editorial page & $0.7 \%$ & $0.7 \%$ & $0.7 \%$ & $0.5 \%$ & $0.7 \%$ \\
& $\mathrm{~N}=2$ & $\mathrm{~N}=1$ & $\mathrm{~N}=1$ & $\mathrm{~N}=1$ & $\mathrm{~N}=5$ \\
Others & $77.9 \%$ & $74.5 \%$ & $88.6 \%$ & $85.2 \%$ & $81 \%$ \\
& $\mathrm{~N}=218$ & $\mathrm{~N}=111$ & $\mathrm{~N}=124$ & $\mathrm{~N}=155$ & $\mathrm{~N}=608$ \\
\hline Total & $100 \%$ & $100 \%$ & $100 \%$ & $100 \%$ & $100 \%$ \\
& $\mathrm{~N}=280$ & $\mathrm{~N}=149$ & $\mathrm{~N}=140$ & $\mathrm{~N}=182$ & $\mathrm{~N}=751$ \\
\hline
\end{tabular}

Table 2 shows that overall, $18 \%$ of the reports were placed on the front page, $0.4 \%$ appeared on centre page, $0 \%$ was on the back page, $0.7 \%$ appeared on the editorial page, while $81 \%$ appeared on other pages. The overwhelming dominance of other pages over front, centre, back and editorial pages (across the four newspapers) is natural because they constitute most of the newspaper space, and so most reports find themselves there. However, for ethnic interest groups to get up to $18 \%$ front page placement is remarkable considering the number of subjects and issues competing for that single but most treasured page in every edition. The centre page almost did not get any material given that only Daily Trust publishes report in that page; others use that mostly for advertisements. Then, the back page, being mainly for opinion columns in the newspapers, had no reports placed on it. For the editorial page, its content is already fixed i.e. editorials, editorial cartoons and letters to the editor. In all, it could be stated that the pattern of placement, to whatever extent, suggests that newspapers placed some value on the activities and communications of the ethnic interest groups; they found them worthy of prominent placement.

Table 3: Page Rating (Excluding Features, Pictures and Editorials)

\begin{tabular}{lccccc}
\hline & & \multicolumn{2}{c}{ Newspapers } & \multicolumn{2}{c}{ Total } \\
& Daily Sun & The Nation & Daily Trust & Vanguard & \\
\hline Page lead & $50.5 \%$ & $21.6 \%$ & $11.6 \%$ & $60 \%$ & $40.1 \%$ \\
& $\mathrm{~N}=106$ & $\mathrm{~N}=25$ & $\mathrm{~N}=32$ & $\mathrm{~N}=96$ & $\mathrm{~N}=240$ \\
Non page lead & $49.5 \%$ & $78.4 \%$ & $88.4 \%$ & $40 \%$ & $59.9 \%$ \\
& $\mathrm{~N}=104$ & $\mathrm{~N}=91$ & $\mathrm{~N}=99$ & $\mathrm{~N}=64$ & $\mathrm{~N}=358$ \\
\hline Total & $100 \%$ & $100 \%$ & $100 \%$ & $100 \%$ & $100 \%$ \\
& $\mathrm{~N}=210$ & $\mathrm{~N}=116$ & $\mathrm{~N}=112$ & $\mathrm{~N}=160$ & $\mathrm{~N}=598$ \\
\hline
\end{tabular}

Table 3 shows that overall, $40.1 \%$ of the reports were published as page lead reports as against $59.9 \%$ that came as non-page lead reports. Ethnic interest groups could be said to have got an impressive share of the page lead reports considering that many other subjects also compete for that status, and there can be only one lead report in each page. Remarkable, 
Volume 1 Number 2

Daily Sun and Vanguard respectively published $50.5 \%$ and $60 \%$ of their reports as page leads.

Table 4: Headline Size (Excluding Pictures, Editorials and Cartoons)

\begin{tabular}{lccccc}
\hline & \multicolumn{2}{c}{ Newspapers } & \multicolumn{2}{c}{ Total } \\
& Daily Sun & The Nation & Daily Trust & Vanguard & \\
\hline Large & $60.5 \%$ & $43.5 \%$ & $23.5 \%$ & $66.1 \%$ & $51.6 \%$ \\
& $\mathrm{~N}=133$ & $\mathrm{~N}=54$ & $\mathrm{~N}=28$ & $\mathrm{~N}=109$ & $\mathrm{~N}=324$ \\
Medium & $8.6 \%$ & $8.9 \%$ & $0 \%$ & $22.4 \%$ & $7.8 \%$ \\
& $\mathrm{~N}=19$ & $\mathrm{~N}=11$ & $\mathrm{~N}=0$ & $\mathrm{~N}=19$ & $\mathrm{~N}=49$ \\
Small & $30.9 \%$ & $47.6 \%$ & $76.5 \%$ & $22.4 \%$ & $40.6 \%$ \\
& $\mathrm{~N}=68$ & $\mathrm{~N}=59$ & $\mathrm{~N}=91$ & $\mathrm{~N}=37$ & $\mathrm{~N}=255$ \\
\hline Total & $100 \%$ & $100 \%$ & $100 \%$ & $100 \%$ & $100 \%$ \\
& $\mathrm{~N}=220$ & $\mathrm{~N}=124$ & $\mathrm{~N}=119$ & $\mathrm{~N}=165$ & $\mathrm{~N}=628$ \\
\hline
\end{tabular}

Table 4 shows the sizes of the headlines of the reports. This was measured by the number of columns across which a headline was spread i.e. "large" (five to six columns), "medium" (three to four columns) or "small" (one to two columns). Overall, 51.6\% of the reports came with large headlines, $7.8 \%$ came with medium headlines, while $40.6 \%$ came with small headlines. Almost a similar pattern is reflected in all but one of the individual newspapers. Looking at the data holistically, it could be stated that the newspapers gave large headlines to a good number of the reports which is a pointer to the extent of value attached to ethnic interest groups by the papers.

On the whole, the foregoing data indicate that the newspapers gave prominence to the activities and communications of the ethnic interest groups in terms of pattern of placement (Table 2), page rating (Table 3), and headline size (Table 4). Such treatment shows prominent coverage of the groups.

RQ3: What issues and events did newspapers report of the ethnic interest groups?

Issues and events reported were measured by examining the subject matter of reports publishedby the newspapers on the groups. Data generated in that regard are as presented in Table 5.

Table 5: Issues Reported of Ethnic Interest Groups

\begin{tabular}{lccccc}
\hline & \multicolumn{4}{c}{ Newspapers } \\
& Daily & The & Daily & Vanguard & \\
& Sun & Nation & Trust & & \\
\hline Advocacy & $29.6 \%$ & $35.6 \%$ & $40.7 \%$ & $25.3 \%$ & $31.8 \%$ \\
& $\mathrm{~N}=83$ & $\mathrm{~N}=53$ & $\mathrm{~N}=57$ & $\mathrm{~N}=46$ & $\mathrm{~N}=239$ \\
Antagonistic communication & $31.4 \%$ & $20.1 \%$ & $17.9 \%$ & $25.8 \%$ & $25.3 \%$ \\
by an ethnic interest group & $\mathrm{N}=88$ & $\mathrm{~N}=30$ & $\mathrm{~N}=25$ & $\mathrm{~N}=47$ & $\mathrm{~N}=190$ \\
Antagonistic communication & $3.6 \%$ & $2 \%$ & $1.4 \%$ & $4.4 \%$ & $3.1 \%$ \\
by government & $\mathrm{N}=10$ & $\mathrm{~N}=3$ & $\mathrm{~N}=2$ & $\mathrm{~N}=8$ & $\mathrm{~N}=23$ \\
Demonstrations/riots/clashes & $4.6 \%$ & $6 \%$ & $7.1 \%$ & $2.7 \%$ & $4.9 \%$ \\
& $\mathrm{~N}=13$ & $\mathrm{~N}=9$ & $\mathrm{~N}=10$ & $\mathrm{~N}=5$ & $\mathrm{~N}=37$ \\
Internal divisions & $0 \%$ & $9.4 \%$ & $2.1 \%$ & $2.2 \%$ & $2.8 \%$ \\
& $\mathrm{~N}=0$ & $\mathrm{~N}=14$ & $\mathrm{~N}=3$ & $\mathrm{~N}=4$ & $\mathrm{~N}=21$ \\
Arrest/trial of members & $18.2 \%$ & $12.8 \%$ & $5.7 \%$ & $19.2 \%$ & $15 \%$ \\
\hline
\end{tabular}


NNAMDI AZIKIWE UNIVERSITY

Volume 1 Number 2

Journal OF COMMUNICATION AND MEDI桑 STUDIES

\begin{tabular}{lccccc}
\hline \multirow{3}{*}{ Ceremonies } & $\mathrm{N}=51$ & $\mathrm{~N}=19$ & $\mathrm{~N}=8$ & $\mathrm{~N}=35$ & $\mathrm{~N}=113$ \\
& $7.9 \%$ & $14.1 \%$ & $3.6 \%$ & $5.5 \%$ & $7.7 \%$ \\
Others & $\mathrm{N}=22$ & $\mathrm{~N}=21$ & $\mathrm{~N}=5$ & $\mathrm{~N}=10$ & $\mathrm{~N}=58$ \\
& $4.6 \%$ & $0 \%$ & $21.4 \%$ & $14.8 \%$ & $9.3 \%$ \\
\hline \multirow{2}{*}{ Total } & $\mathrm{N}=13$ & $\mathrm{~N}=0$ & $\mathrm{~N}=30$ & $\mathrm{~N}=27$ & $\mathrm{~N}=70$ \\
& $100 \%$ & $100 \%$ & $100 \%$ & $100 \%$ & $100 \%$ \\
& $\mathrm{~N}=280$ & $\mathrm{~N}=149$ & $\mathrm{~N}=140$ & $\mathrm{~N}=182$ & $\mathrm{~N}=751$ \\
\hline
\end{tabular}

Table 5 indicates that $31.8 \%$ of the reports on ethnic interest groups were on advocacy, $25.3 \%$ were on antagonistic communication by an ethnic interest group, $3.1 \%$ on antagonistic communication by government, $4.9 \%$ on demonstrations/riots/clashes, $2.8 \%$ on internal divisions, $15 \%$ on arrest/trial of members, $7.7 \%$ on ceremonies, while $9.3 \%$ was on other issues. Thus, the newspapers largely reported the ethnic interest groups in terms of the advocacy they make; the ideas they promote and what they want done.

This suggests that they tend to view them as important voices in the national discourse whose opinions and suggestions on the nation should be heard. Similarly, antagonistic communication by these groups was frequently reported as well; this sort of communication is usually in the form of aggressive demands, warnings and accusations by the groups. It is often dramatic and sensational and so makes the typical sort of audience-pulling news that interests the press (Jenkins, 1981; Hieber, 1998; Akin, 2005). Also, the relative dominance of arrest/trial of members among the issues reported of the groups may be understood also by paying attention to the typically dramatic nature of such occurrence which became a common experience of more radical groups like MASSOB and IPOB.

\section{RQ4: What were the slants of newspaper reports on the ethnic interest groups?}

Slant was measured by examining the direction of reports in the papers in terms of how favourable it appeared to the respective ethnic interest groups. Data generated in that regard are as presented in Table 6.

Table 6: Slant

\begin{tabular}{lccccc} 
& & \multicolumn{2}{c}{ Newspaper } & \multicolumn{2}{c}{ Total } \\
& Daily Sun & The Nation & Daily Trust & Vanguard & \\
\hline Favourable to an & $7.1 \%$ & $3.4 \%$ & $45 \%$ & $2.2 \%$ & $12.3 \%$ \\
$\begin{array}{l}\text { Hausa-Fulani interest } \\
\text { group }\end{array}$ & $\mathrm{N}=20$ & $\mathrm{~N}=5$ & $\mathrm{~N}=63$ & $\mathrm{~N}=4$ & $\mathrm{~N}=92$ \\
$\begin{array}{l}\text { Favourable to an Igbo } \\
\text { interest group }\end{array}$ & $51.8 \%$ & $12 . \%$ & $15.6 \%$ & $45.1 \%$ & $35.6 \%$ \\
Favourable to a & $\mathrm{N}=145$ & $\mathrm{~N}=18$ & $\mathrm{~N}=22$ & $\mathrm{~N}=82$ & $\mathrm{~N}=267$ \\
Yoruba interest group & $17.9 \%$ & $30.9 \%$ & $10.7 \%$ & $3.8 \%$ & $15.7 \%$ \\
Favourable to a & $\mathrm{N}=50$ & $\mathrm{~N}=46$ & $\mathrm{~N}=15$ & $\mathrm{~N}=7$ & $\mathrm{~N}=118$ \\
minority interest & $13.2 \%$ & $9.4 \%$ & $5.7 \%$ & $27.5 \%$ & $14.5 \%$ \\
group & $\mathrm{N}=37$ & $\mathrm{~N}=14$ & $\mathrm{~N}=8$ & $\mathrm{~N}=50$ & $\mathrm{~N}=109$ \\
No Clear Slant & $10 \%$ & $44.3 \%$ & $22.9 \%$ & $21.4 \%$ & $22 \%$ \\
& $\mathrm{~N}=28$ & $\mathrm{~N}=66$ & $\mathrm{~N}=32$ & $\mathrm{~N}=39$ & $\mathrm{~N}=165$ \\
\hline Total & $100 \%$ & $100 \%$ & $100 \%$ & $100 \%$ & $100 \%$ \\
& $\mathrm{~N}=280$ & $\mathrm{~N}=149$ & $\mathrm{~N}=140$ & $\mathrm{~N}=182$ & $\mathrm{~N}=751$ \\
\hline
\end{tabular}


Table 6 shows that on the whole (across the four newspapers), 12.3\% of the reports were favourable to Hausa-Fulani ethnic interest groups, 35.6\% to an Igbo interest group, $15.7 \%$ favoured Yoruba groups, $14.5 \%$ favoured minority groups, while $22 \%$ came with no clear slant. Interestingly, it can be observed that the news slants largely followed the ethnicity of the proprietors of the newspapers; each of the papers tended to give more positive slant to the ethnic group where the owner(s) come from. However, the exception was Vanguard which gave the most positive slants to Igbo interest groups while minority groups (where the proprietor belongs) came second. This same pattern was also seen of Vanguard in the amount of reports published of the ethnic interest groups (Table 2).

\section{RQ5: What was the likely influence of owner's ethnicity on newspaper coverage of the groups?}

To measure the likely influence of owners' ethnicity, ethnic background was correlated with the pattern of the reportage. This is as presented in Table 7.

Table 7: Zero Order Correlation Matrix (Pearson's Product Moment Correlation Coefficient)

\begin{tabular}{lcccccc}
\hline & 1 & 2 & 3 & 4 & 5 & 6 \\
\hline 1. Owners'ethnicity & 1 & -.025 & $-.235^{* *}$ & $-.257^{* *}$ & $.332^{* *}$ & $176^{* * *}$ \\
2.Placement & & 1 & $.259^{* *}$ & $.310^{* *}$ & $.072^{* *}$ & -.006 \\
3. Page rating & & & 1 & $.774^{* *}$ & .066 & -.016 \\
4. Headline size & & & & 1 & .025 & -.041 \\
5. Ethnic group reported & & & & & 1 & $.327^{* *}$ \\
6. Slant & & & & & & 1 \\
\hline
\end{tabular}

Correlation is significant at the 0.01 level (2-tailed).

* Correlation is significant at the 0.05 level (2-tailed).

Table 7 shows that owners' ethnicity correlates negatively with page rating $(r=-.235)$ and headline size $(\mathrm{r}=-.257)$, and positively with ethnic group reported $(\mathrm{r}=.332)$, and slant $(\mathrm{r}=$ 176). This indicates that a likelihood of association between ethnic backgrounds of the respective newspaper proprietors and how they report the ethnic interest groups exist. Instructively, influence of owners' ethnicity in reporting ethnic issues in Nigeria has been observed in previous studies including Sule (2015), Omenugha and Ukwueze (2011), and Ngwuet al. (2013).

\section{DISCUSSION OF FINDINGS}

The finding by this study showed that the newspapers gave frequent and prominent coverage to the ethnic interest groups is an indication that the papers viewed these groups as deserving of being kept on the public agenda. Frequent and prominent coverage is the most critical element in the agenda setting process, as subjects accorded such treatment by the media are likely to emerge as part of the public agenda (Daramola, 2003; Baran, 2010). This finding may have been lent credence by the assertion of Sule (2015) that ethnic interest groups and ethnicity-related issues are dominant in the sphere of public discussion and debate in Nigeria. In this light, one could state that these subjects have gained their prominent status due to the manner in which the newspapers, and perhaps, other mass media, have treated them. However, this is after allowance must have been made for other intervening variables that might influence the agenda setting process. 
The third finding would also advance the argument that the press views ethnic interest groups as significant voices that ought to be heard, as the papers largely reported them in terms of the advocacy they make, the ideas they promote and the demands they make. The finding also showed frequent reportage of antagonistic communication of these groups by way of their aggressive demands, warnings and accusations; a pattern that validates the belief that the press often gives dramatic and sensational treatment to divisive subjects like ethnicity as a way of exciting audience interest (Jenkins, 1981; Hieber, 1998; Akin, 2005).

Similarly, results equally indicate that the respective newspapers slanted their coverage in favour of particular ethnic interest groups and that this slanting corresponded with the ethnicity of the respective owners. This suggests that the coverage is reflective of the beliefs, biases and prejudices upheld about ethnicity in Nigeria. Interestingly, influence of ethnic ideology on reportage in the country has been investigated by several previous studies including Omenugha and Ukwueze (2011), Medubi (2012), Ngwu et al. (2013), Salawu (2013), Nwafor (2015) and Sule (2015) - with the results generally showing that this influence is real and strong. Studies such as Ekeanyanwu (2007), Ngwu et al. (2013) and (2013) Sule (2015) were also interested in the role of ownership in this influence, and just like the present study, the ethnicity of the owner was found to be significant.

\section{CONCLUSION}

Based on the findings of the study, it may be concluded that the continued visibility enjoyed by ethnicity-related issues in the sphere of public discourse in Nigeria may be partly explained by the frequent and prominent coverage which this study found newspapers to be giving to ethnic interest groups. Such coverage, according to the agenda setting theory, is critical for elevating an issue to the level of public agenda. Furthermore, the fact that the newspapers slanted their reports in favour of ethnicity of their owners underscores media's role in reinforcing ethnic consciousness and divisiveness in Nigeria as found by several previous studies (Salawu, 2007; Omenugha \& Ukwueze, 2011; Ngwu et al., 2013; Nwafor, 2015; Sule, 2015). So, in effect, findings of this study validate results of previous studies to the effect that media coverage of ethnicity has been largely biased, with the ethnicity of the owner influencing the slant.

\section{RECOMMENDATIONS}

1. Newspaper houses in Nigeria should work towards improving objectivity in their representation of ethnic interest groups through adopting deliberate editorial policies aimed at giving even amounts of coverage to different ethnic interests as well as reporting them fairly irrespective of whatever interest a newspaper house might have.

2. Given how sensitive and emotive ethnicity-related issues have proven in Nigeria and other places (Umejesi, 2012), there is need for periodic internal review of performances of Nigerian newspapers. This could be done under the auspices of bodies like the Nigeria Union of Journalists (NUJ), Nigerian Guild of Editors (NGE) and Nigerian Press Council, among others. The aim will be to continually appraise how much practitioners have been faithful to the established norms of practice in terms of equal representation and objectivity. Such peer review mechanism could help individual journalists and newspaper houses to continuously improve their performance without threat to press freedom.

3. A repeat of this study using other newspapers different from those employed in this study may be necessary. For instance, based on ethnic backgrounds of owners (which 
Volume 1 Number 2

informed the researcher's choice of newspapers), The Punch could be substituted for The Nation,The Authority for Daily Sun, New Nigerian for Daily Trust and The Guardian for Vanguard. Study of these other newspapers may help in further validating the generalisations made in the present study.

4. In the same vein, other media forms such as radio and television should also be subjected to this sort of study. This is important given that various media forms have their various unique characteristics and dynamics. For instance, television, given its greater capacity to graphically depict and glamorise events, has injected much dramatisation to political events (Lewis, 2005) such as represented by ethnic relations in Nigeria.

\section{REFERENCES}

Ademola, A. (2009). Ethnicity, party politics and democracy in Nigeria: People's Democratic Party (PDP) as agent of consolidation? Stud Tribes Tribals, 7(1), 1-9.

Adetoye, D. (2016). Ethnicity and state creation in Nigeria: Exploring the nexus between the Babel of tongues and institutionalization. International Journal of Economics, Commerce and Management, IV (4), 1 - 12.

Ajayi, J. O. \&Owumi, B. (2013), Ethnic pluralism and internal cohesion in Nigeria.International Journal of Development and Sustainability, 2(2), 926 - 940.

Akin, J. (2005).Additional insight into the mass media. Retrieved from http://www.beyondintractability.org

Ardèvol-Abreu, A. (2015). Framing theory in communication research in Spain.Origins, development and current situation.Revista Latina de Comunicación Social, 70, 423 450. Retrieved from http://www.revistalatinacs.org/070/paper/1053/23en.html

Arewa Consultative Forum.(2016). History of (Arewa Consultative Forum). Retrieved from http://acf.com.ng/aboutus.html

Ayatse, F. H. \&Akuva, I. I. (2013). The origin and development of ethnic politics and its impacts on post-colonial governance in Nigeria.European Scientific Journal, 9(17), 178 $-189$

Baran, S. J. (2010).Introduction to mass communication, media literacy and culture (6 $6^{\text {th }}$ ed.). New York: McGraw-Hills.

Bellhouse, D. R. (2005).Systematic sampling methods.Retrieved from http://onlinelibrary.wiley.com/doi/10.1002/0470011815.b2a16077/abstract

Blench, R. \&Dendo, M. (2003). Position paper: The dimensions of ethnicity, language and culture in Nigeria. Retrieved from http://www.rogerblench.info/Development/Nigeria/Economic\%20development/Ethnicity \%20Position\%20Paper\%20Blench\%20short.pdf 
Chong, D. \& Druckman, J. N. (2007a).A theory of framing and opinion formation in competitive elite environments.Journal of Communication, 57, 99-118.

Chong, D. \& Druckman, J. N. (2007b).Framing theory.Annual Review Political Science, 10, $103-26$.

Daramola, I. (2013). Ethnic consideration in political coverage by Nigerian media.KuwaitChapter of Arabian Journal of Business and Management Review, 2(12), $38-52$.

Doki, A. M. (n.d.). Mass media and conflicts in northern Nigeria. Retrieved from www.imim-ng.org/downloads/Abdullahi\%20paper.doc

Ebegbulem, J. C. (2001). Ethnic politics and conflicts in Nigeria: Theoretical perspective. Khazar Journal of Humanities and Social Sciences 3(5): 76 - 91. Retrieved from http://dspace.khazar.org/jspui/bitstream/123456789/1372/1/07Ethnic\%20Politics\%20and \%20Conflicts\%20in\%20Nigeria\%20-\%20BITDI.pdf

Edewor, P. A., Aluko, Y. A. \& Folarin, S. F. (2014).Managing ethnic and cultural diversity for national integration in Nigeria.Developing Country Studies 4(6), 70 - 76.

Ekeanyanwu, N. T. (2007). The Nigerian press coverage of political conflicts in a pluralistic Society. Retrieved from http://eprints.covenantuniversity.edu.ng/946/1/PRESS\%20COVERAGE\%20IN\%20GL OBAL\%20MEDIA\%20JOURNAL\%20AFRICAN\%20EDITION.pdf

Ekeanyanwu, N .T. (2013). Media freedom, political conflicts and the Nigerian cultural dialectics: The American example. In U. Pate, C. Nwabueze, \& S. Idiong (Eds.), Politics, culture and the media in Nigeria (p.139 - 155). Ibadan: Stirling-Horden Publishers Limited.

Jenkins, B. M. (1981). The psychological implications of media-covered terrorism.California: The Rand Corporation.

Kukah, M. H. (2012). Religion, politics and power in northern Nigeria.Ibadan: Spectrum.

Kukah, M. H. (2012). Witness to justice: An eyewitness account of the Nigeria's truth commission. Ibadan: Book Kraft.

Lewis, J. (2005). Language wars:The role of media and culture in global terror and political violence. London: Pluto.

McQuail, D. (2010). McQuail's mass communication theory: An introduction (6th ed.). Beverly Hills CA: Sage.

Ndujihe, C. (2011). Unending bomb explosions: Which way out?Retrieved from allafrica.com/stories/201106061694.html. 
Ngwu, C. C., Ekwe, O. \& Chukwuma, O. (2013).When ownership and geographical considerations get to the front burner in media coverage of political crisis: A critical review.Research on Humanities and Social Sciences, 3(18), 113 - 118

Nikitin, P. I. (1983). The fundamentals of political economy. Moscow: Progress.

Njoroge, M. C., Kimani, P. \&Kikech, B. J. (2011). New media in Kenya: Putting ethnicity in perspective. In D. N. Wachanga (Ed.), Cultural identity and new communication technologies: Political, ethnic and ideological implications (pp.40 - 65). New York: International Science Reference.

Nnoli, O. (1978). Ethnic politics in Nigeria. Enugu. Fourth Dimension.

Nnoli, O. (1995). Ethnicity and development in Nigeria.Aldershot: Avebury.

Nwafor, K. A. (2015). Media frames of group identities in the 2014 national dialogue in Nigeria: An analysis of the Daily Sun and Leadership newspapers. Afro Asian Journal of Social Sciences 6(3): $1-23$.

OhanaezeNdi-Igbo, Enugu State Chapter (2015).History.Retrieved from http://ohanezendigboenugu.org/

Ojie, A. E. \&Ewhrudjakpor, C. (2009).Ethnic diversity and public policies in Nigeria.Anthropologist, 11(1), 7-14. Retrieved from http://www.krepublishers.com/02Journals/T-Anth/Anth-11-0-000-09-Web/Anth-11-1-001-09-Abst-PDF/Anth-11-1-00709-531-Ojie-A-E/Anth-11-1-007-09-531-Ojie-A-E-Tt.pdf

Ojoma, E. O. (2015, April 4). Ethnicity continues to divide Nigeria. National Mirror, p.19.

Omenugha, K. A. \&Ukwueze, C. (2011). The enemy within: Exploring media reports of crises and normative perspectives in Nigeria." In O. Omojola (Ed.), Communication aspects of conflicts and terrorism (pp.111 - 126). Lagos: Corel Service.

Omoniyi, T. (2014). 'The man from Africa is on his way': Styling in Nollywood films. Covenant Journal of Language Studies (CJLS), 2(2), 100 - 126.

Orizu, A. A. (1994). Liberty or chains - Africa must be: An autobiography.Nnewi: Horizontal Publishers.

Sagay, I. (2009, May 9). Why there are ethnic crises in the North. Saturday Champion, pp.11 -42 .

Salawu, A. (2013). Recall of politics of identity in the narratives of the Nigerian press. Journal of Communication, 4(1), 41 - 48

Scheufele, D. A. (1999).Framing as a theory of media effect.Journal of Communication. 103 -112 .

Sule, R. N. (2015). Ethno-religious conflicts, mass media and national development: The northern Nigeria experience (Doctoral dissertation, University of Jos, Jos, Nigeria). 
NNAMDI AZIKIWE UNIVERSITY Journal of COMMUNICATION AND MEDIA STUDIES

Volume 1 Number 2

Retrieved from http://irepos.unijos.edu.ng/jspui/bitstream/123456789/1147/1/RAPHAEL\%20NOAH\%2 OSULE.pdf

Taiwo, R. (2007). Language, ideology and power relations in Nigerian newspaper headlines.Nebula, 4(1), $218-245$.

Ukiwo, O. (2005). On the study of ethnicity in Nigeria.Crise working paper no. 12. Oxford: Centre for Research on Inequality, Human Security and Ethnicity (CRISE) Queen Elizabeth House, University of Oxford.

Umejesi, I. (2012). The nation state, resource conflict, and the challenges of "former sovereignties" in Nigeria.African Studies Quarterly, 13(3), 47 - 66.

Vande, P. T. (2012). Ethnicity and the politics of state creation in Nigeria.European Scientific Journal, 8(16), $33-51$.

Waters, M .C. (2009). Optional ethnicities: For whites only? In G. Massey (Ed.), Readings for sociology $\left(6^{\text {th }}\right.$ ed., pp. $\left.217-226\right)$. New York: W. W. Norton \& Company Inc. 